\title{
Evaluasi Ekonomi Teknik Produksi Keripik Kentang Secara Manual (Studi Kasus : Taman Teknologi Pertanian, Cikajang, Kabupaten Garut, Provinsi Jawa Barat)
}

Economic Engineering Evaluation of Potato Chips Production by Manual Procces (Case Study: Agriculture Technology Park, Cikajang, Regency of Garut, West Java Province)

\author{
Ahmad Thoriq ${ }^{1}$, Rizky Mulya Sampurno" ${ }^{1)}$ Sarifah Nurjanah ${ }^{1)}$ \\ ${ }^{1)}$ Staf Pengajar Departemen Teknik Pertanian dan Biosistem, FTIP, Universitas Padjadjaran \\ JI. Raya Bandung Sumedang KM 21, Jatinangor 40600 \\ Email : thoriq.unpad@gmail.com
}

\begin{abstract}
ABSTRAK
Agroindustri kentang merupakan unit usaha utama yang dikelola Taman Teknologi Pertanian, Cikajang, Garut. Kentang yang dikembangkan difokuskan pada kentang industri varietas median. Hasil produksi sebagian dijual dalam bentuk mentah ke Industri keripik kentang dan sebagian lagi diolah sendiri menjadi keripik kentang yang dipasarkan sendiri. Meskipun terdapat beberapa unit mesin, namun produksi keripik kentang masih dilakukan secara manual menggunakan peralatan sederhana, sehingga untuk keberlanjutan usaha perlu dilakukan evaluasi ekonomi usaha produksi keripik kentang yang diolah secara manual. Metode yang digunakan pada penelitian ini analisis ekonomi yang meliputi biaya produksi, harga pokok produksi, titik impas dan kelayakan usaha yang meliputi Net Present value (NPV), benefit cost ratio analysis (BC Rasio), Internal Rate of Return (IRR) dan payback period analysis (PBP). Berdasarkan analisis ekonomi, pada umur proyek lima tahun didapatkan HPP keripik kentang sebesar Rp.72.816 perkg, dengan titik impas $600 \mathrm{~kg}$ pertahun, BC Rasio sebesar 1,25, NPV sebesar Rp 137.299.137 pertahun, IRR sebesar 16,42 \%, dan PBP selama sembilan bulan.
\end{abstract}

Kata kunci : analisis ekonomi, kelayakan usaha, keripik kentang, pengolahan manual

\section{ABSTRACT}

Potato agroindustry is the main business unit managed by Taman Teknologi Pertanian, Cikajang, Garut. The developed potatoes are focused on median varieties of industrial potatoes. The produce is partly sold in raw form to the Potato Chips Industry and partly processed itself into self-marketed potato chips. Although there are several machine units, but the production of potato chips is still done manually using simple equipment, so for the sustainability of the business needs to be evaluated economic production of potato chips which are processed manually. The methods used in this study are economic analysis covering production cost, cost of production, breakeven and business feasibility which include Net Present Value (NPV), benefit cost ratio analysis (BC ratio), Internal Rate of Return (IRR) and payback period analysis (PBP). Based on the economic analysis, at the age of the five-year project was obtained HPP potato chips Rp.72.816 per $\mathrm{kg}$, with a break even $600 \mathrm{~kg}$ per year, BC Ratio of 1.25, NPV of Rp 137.299.137 per year, IRR of 16.42\%, and PBP for nine months.

Keywords: economic analysis, business feasibility, potato chips, manual processing

Diterima : 6 Agustus 2017 ; Disetujui : 29 Agustus 2017; Online Published : 26 Oktober 2017 DOI : $10.24198 /$ jt.vol11n2.5 


\section{PENDAHULUAN}

Taman Teknologi Pertanian (TTP) Cikajang, Garut dibangun pada tahun 2015 oleh Kementerian Pertanian melalui Badan Penelitian dan Pengembangan Pertanian bekerjasama dengan Pemerintah Daerah Kabupaten Garut, Universitas Padjajaran dan Universitas Garut. Pembangunan TPP Cikajang bertujuan untuk mewujudkan salah satu Nawacita Bapak Presiden Joko Widodo.

Target utama TTP Cikajang adalah meningkatkan nilai tambah dan daya saing produk pertanian lokal sebagai daya ungkit skala ekonomi dari usaha tani melalui penerapan teknologi di lokasi usaha tani yang difokuskan pada tiga komoditi utama yaitu kentang industri, domba dan jeruk Garut (Syakir, 2016). Pengembangan komoditi utama tersebut didasarkan pada potensi wilayah setempat dimana daerah Cikajang, Kabupaten Garut bersama dengan daerah Pengalengan, Kabupaten Bandung merupakan penyuplai utama kentang ke wilayah Jabotabek.

Kentang yang diproduksi oleh sebagian besar petani di Cikajang adalah kentang sayur varietas granola dan kentang industri. Selama ini bahan baku industri keripik kentang berasal dari varietas Atlantik namun sayang pengadaan benihnya masih bergantung pada impor, selain itu varietas Atlantik tidak tahan terhadap penyakit hawar daun (Phythophthora infestans) (Sofiari dkk, 2015). Petani membudidayakan kentang varietas Atlantik melalui sistem contract farming dengan (PT. IFM) yang menyediakan benih Atlantik dan petani menjualnya ke perusahaan (Rahayu dan Kartika, 2015). Pola kemitraan tersebut mampu menarik minat lembaga non-Bank untuk memberikan bantuan modal usaha, terutama untuk pembiayaan modal kerja (Bank Indonesia, 2017). Namun pola kemitraan secara berangsur sudah mulai ditinggalkan karena petani merasa lebih banyak dirugikan (Rahayu dan Kartika, 2015).

Pada periode tahun 2000-2014, Badan Penelitian Sayuran (Balitsa) telah melepas sebanyak 21 Varietas Unggul Baru (VUB). Varietas Medians telah dilisensikan kepada PT. Papandayan Cikuray Farm Cikajang Garut sejak tahun 2013. Varietas Andina dan Amabile sedang dalam proses lisensi oleh PT DAFA, dan varietas GM 05 sedang diproses untuk lisensi oleh PT. Pupuk Kujang (Sofiari dkk, 2015).

Saat ini TPP Cikajang telah melakukan budidaya kentang industri menggunakan varietas Medians. Hasil produksi sebagian dijual dalam bentuk mentah ke Industri keripik kentang dan sebagian lagi diolah sendiri menjadi keripik kentang yang dipasarkan sendiri. Meskipun terdapat mesin pengolahan keripik kentang di antaranya pengupas, dan pengiris, namun produksi keripik kentang masih dilakukan secara manual. Salah satu penyebabnya adalah belum terbiasa dalam pengoperasian mesin dan belum adanya kontinyuitas produksi karena lemahnya akses pemasaran. Penelitian ini bertujuan melakukan evaluasi ekonomi yang mencakup harga pokok produksi, titik impas, dan kelayakan usaha produksi keripik kentang yang diolah secara manual.

\section{METODOLOGI PENELITIAN}

\section{Waktu dan Tempat}

Penelitian dilakukan pada bulan Maret sampai Juni 2017 bertempat di Taman Teknologi Pertanian, Cikajang, Kabupaten Garut. 


\section{Bahan dan Alat}

Bahan yang digunakan pada penelitian ini adalah kentang industri varietas Medians. Sedangkan alat yang digunakan pada penelitian ini adalah pisau, alat pengiris kentang (Gambar 1), stop watch, timbangan digital, baskom dan alat tulis.

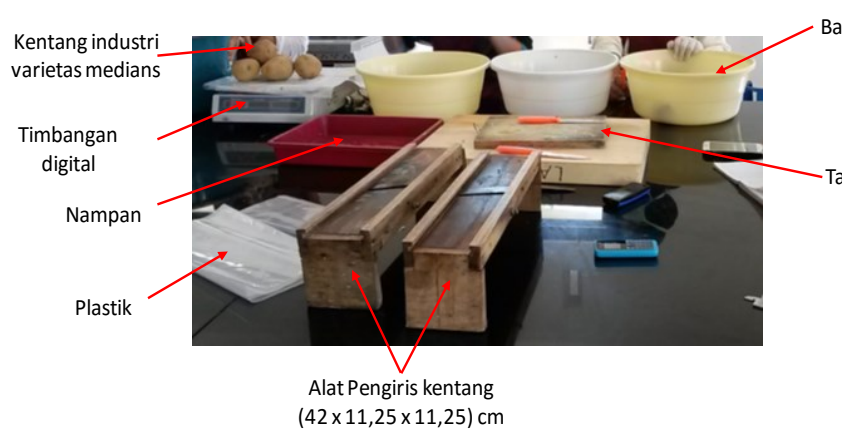

Gambar 1. Peralatan penelitian

Pengupasan kentang dilakukan dengan menggunakan pisau dengan cara mengupas kulit kentang satu persatu sedangkan pengirisan kentang dilakukan menggunakan pisau dan ala pengiris. Penggunaan alat pengiris dilakukan dengan cara menggesekkan kentang yang telah dikupas ke bagian atas alat pengiris dimana bagian tersebut terdapa pisau sehingga kentang bergesekan secara langsung dengan pisau. Kentang yang telah teriris akan jatuh ke bagian bawah pisau.

\section{Metode Pengumpulan Data}

Data yang digunakan berupa data primer dan sekunder. Data primer diperoleh melalui wawancara mendalam, dan diskusi dengan pengelola usaha keripik kentang, sedangkan data sekunder dikumpulkan melalui publikasi ilmiah yang berkenaan dengan keripik kentang. Prosedur penelitian yang dilakukan adalah asumsi dan pendekatan sebagai dasar dalam melakukan perhitungan dan analisis. Asumsi dan pendekatan yang digunakan terdiri dari: (1) umur ekonomis peralatan produksi adalah 5 tahun, (2) harga akhir peralatan adalah 10\% dari harga awal, (3) tingkat suku bunga $9 \%$ efektif pertahun, (4) sewa tempat usaha Rp 5.000.000/tahun, honor manajemen/manajer Rp. 18.000.000/tahun, (6) biaya perawatan peralatan $2 \% /$ tahun, (7) waktu kerja 8 jam perhari dan 10 hari tiap bulan, (8) harga bahan baku Rp. 10.000 perkg, (9) harga kemasan Rp.850/kemasan, (10) konsumsi bahan bakar gas 0,3 kg/hari.

\section{Metode Analisis}

\section{1) Analisi penyusutan}

Besarnya biaya penyusutan peralatan produksi diperhitungkan dengan menggunakan metode garis lurus yang dirumuskan sebagai berikut :

$$
D=\frac{P-S}{N}
$$

Keterangan :

$\mathrm{D}=$ biaya penyusutan pertahun (Rp/tahun)

$\mathrm{P}=$ harga awal peralatan $(\mathrm{Rp})$

$\mathrm{S}=$ harga akhir peralatan $(\mathrm{Rp})$

$\mathrm{N}=$ perkiraan umur ekonomis (tahun)

\section{2) Perhitungan bunga}

Bunga merupakan nilai jasa atas penggunaan uang yang dihitung menurut waktu. Terdapat dua jenis suku bunga yaitu suku bunga nominal dan suku bunga efektif. (Kastaman, 2004). Hubungan suku bunga efektif dan suku bunga nominal dirumuskan seperti pada persamaan 2 .

$$
\mathrm{i}_{\text {eff }}=(1+\mathrm{r} / \mathrm{M})^{\mathrm{M}}-1
$$

Keterangan :

$\mathrm{i}_{\text {eff }}=$ suku bunga efektif

$r$ = suku bunga nominal tahunan

$\mathrm{i}$ = suku bunga nominal per periode

$\mathrm{M}=$ jumlah periode majemuk per satu tahun

Berdasarkan persamaan 2, besarnya suku bunga efektif akan lebih besar dibandingkan dengan suku bunga nominal. Sebagai contoh bila suku bunga efektif $9 \%$ pertahun maka dengan menggunakan 
persamaan 2, suku bunga nominal adalah $8,74 \%$ pertahun.

\section{3) Analisis biaya produksi}

Biaya produksi merupakan penjumlahan biaya tetap dan biaya variabel. Besarnya biaya produksi di hitung menggunakan persamaan 3 sebagai berikut:

$B P=B T+B V$

Keterangan :

$$
\begin{array}{ll}
\text { BP } & =\text { Biaya Produksi (Rp/tahun) } \\
\text { BT } & =\text { Biaya Tetap (Rp/tahun) } \\
\text { BV } & =\text { Biaya Variabel (Rp/tahun) }
\end{array}
$$

\section{4) Analisis harga pokok produksi}

Harga pokok produksi adalah jumlah biaya yang dikeluarkan untuk memproduksi suatu barang, sehingga barang tersebut dapat digunakan.Harga pokok dapat dihitung dengan menggunakan persamaan berikut :

$$
\mathrm{HPP}=\mathrm{BP} / \mathrm{PT}
$$

Keterangan :

$$
\begin{aligned}
& \text { HPP = Harga Pokok Produksi (Rp/unit) } \\
& \text { BP = Biaya produksi (Rp/tahun) } \\
& \text { PT = Produksi Total (unit/tahun) }
\end{aligned}
$$

\section{5) Titik impas produksi}

Analisa titik impas adalah suatu cara untuk mengetahui volume produksi berapakah perusahaan tersebut mengalami kerugian atau mendapat keuntungan. Menurut Pramudya dan Dewi (1992), untuk menghitung titik impas produksi dapat digunakan rumus :

$$
\mathrm{BEP}=\frac{\mathrm{BT}}{\mathrm{HJ}-\mathrm{BVR}}
$$

Keterangan :

$$
\begin{aligned}
& \text { BEP = Titik Impas Produksi } \\
& \text { (unit/tahun) } \\
& \text { BT = Biaya Tetap (Rp/tahun) }
\end{aligned}
$$

$$
\begin{aligned}
& \mathrm{HJ}=\text { Harga jual (Rp/unit) } \\
& \mathrm{BVR}=\text { Biaya Variabel Rata-rata } \\
& \text { (Rp/unit) }
\end{aligned}
$$

\section{6) Analisis kelayakan investasi}

Kelayakan investasi suatu usaha dilihat dari beberapa parameter yaitu NPV, BCR, IRR dan PBP. Suatu usaha dikatakan layak bila NPV $>0, B C R>1$, IRR > Suku bunga MARR, dan pengembalian modal yang cepat (Kastaman, 2004).

\section{a) Net Present Value (NPV)}

Metode ini didasarkan atas nilai sekarang bersih dari perhitungan dana masuk (penerimaan) dan dana keluar (pengeluaran) selama jangka waktu analisis dan suku bunga yang diacu pada penelitian ini adalah suku bunga kredit usaha rakyar mikro PT. Bank Republik Indonesia, Tbk yaitu sebesar 9\% efektif pertahun. Perhitungan NPV dirumuskan dengan sebagai berikut :

$$
\mathrm{NPV}=(\Sigma \text { PVin })-(\Sigma \text { PVout })
$$

\section{b) Payback Period Analysis (PBP)}

Pada metode ini tidak digunakan perhitungan dengan menggunakan rumus bunga,akan tetapi yang dianalisis adalah seberapa cepat modal atau investasi yang telah dikeluarkan dapat segera kembali. Kriteria penilaiannya adalah semakin singkat pengembalian investasi akan semakin baik.

\section{c) Benefit Cost Ratio Analysis (BCR)}

BCR merupakan perbandingan antara nilai sekarang dari penerimaan atau pendapatan yang diperoleh dari kegiatan investasi dengan nilai sekarang dari pengeluaran (biaya) selama investasi tersebut berlangsung dalam 
kurun waktu tertentu yang dirumuskan dengan :

$B C R=\frac{(\Sigma \text { Nilai Sekarang Pendapatan })}{(\Sigma \text { Nilai sekarang Pengeluaran })}$

\section{d) Internal Rate of Return (IRR)}

Syarat kelayakannya yaitu apabila IRR > suku bunga MARR. Suku bunga yang diacu pada penelitian ini adalah suku bunga kredit usaha rakyar mikro PT. Bank Republik Indonesia, Tbk yaitu sebesar 9\% efektif pertahun. Untuk menghitung IRR dapat digunakan cara coba-coba dengan formula berikut:

$I R R=\frac{i 1-N P V 1 x(i 2-i 1)}{(N P V 2-N P V 1)}$

Keterangan :

$\mathrm{i}_{1}=$ suku bunga ke-1

$\mathrm{i}_{2}=$ suku bunga ke-2

$\mathrm{NPV}_{1}=$ Net Present Value pada

suku bunga ke-1

$\mathrm{NPV}_{2}=$ Net Present Value pada

suku bunga ke-2

\section{HASIL DAN PEMBAHASAN}

\section{Gambaran Usaha Pengolahan Kentang di TPP, Cikajang, Garut}

Kentang merupakan salah satu usaha unggulan di TPP, Cikajang. Kentang yang dikembangkan difokuskan pada jenis kentang industri varietas Medians. Menurut Kusandriani (2014) varietas Medians sangat cocok digunakan sebagai bahan baku keripik kentang karena memiliki kandungan pati, karbohidrat, gula reduksi, dan kadar air yang lebih unggul dibandingkan varietas lainnya. Selain itu produktivitasnya cukup tinggi berkisar antara $24,9-25,7$ ton/hektar.

Usaha kentang yang dikembangkan berbasis agroindustri mulai dari hulu sampai hilir. Industri hulu berupa produksi benih kentang berbasis konvensional dan aeroponik serta usahatani kentang. Usaha tani kentang yang dikembangkan berbasis kemitraan dengan kelompok tani di lingkungan TPP Cikajang sehingga keberadaan TPP Cikajang dirasakan manfaatnya secara langsung bagi peningkatan ekonomi masyarakat. Hasil produksi sebagian besar dijual dengan industri pengolahan kentang mitra TPP Cikajang dan sebagian lagi di olah menjadi keripik kentang.

Produksi keripik kentang yang dilakukan di TPP Cikajang masih dilakukan berdasarkan pesanan (belum kontinyu) karena masih terkendala faktor pemasaran. Tenaga kerja dan pengelola industri pengolahan keripik kentang dilakukan oleh kelompok wanita tani. Produksi keripik kentang sebagian besar masih dikerjakan secara manual menggunakan peralatan sederhana terutama pada bagian pengupasan dan pengirisan, meskipun sebenarnya terdapat mesin pengolahan kentang namun belum dimanfaatkan secara optimal karena beberapa faktor diantaranya : 1). Kentang hasil produksi mesin masih kurang baik sehingga diperlukan modifikasi beberapa komponen mesin, 2). Beberapa komponen mesin telah mengalami kerusakan karena kurangnya pengetahuan dalam pengoperasian mesin, 3) Permintaan keripik kentang masih rendah dan belum kontinyu

\section{Evaluasi Ekonomi}

Evaluasi ekonomi dilakukan pada produksi keripik kentang yang diiris menggunakan alat pengiris. Hal ini karena kualitas keripik kentang yang dihasilkan dengan menggunakan alat pengiris lebih baik dibandingkan dengan diiris meggunakan pisau.

\section{a. Investasi Usaha}

Investasi adalah penanaman uang atau modal dalam suatu perusahaan atau proyek untuk tujuan memperoleh keuntungan (KBBI,2017). Kebutuhan investasi suatu usaha ditentukan berdasarkan peralatan dan bahan yang diperlukan selama jangka waktu usaha tertentu (Kastaman, 2004). Pada usaha 
produksi keripik kentang secara manual, dibutuhkan investasi peralatan produksi seperti dapat dilihat pada Tabel 1.

Tabel 1. Biaya investasi usaha produksi keripik kentang

\begin{tabular}{clcccc}
\hline No & Nama peralatan & Jumlah & Satuan & Harga Satuan (Rp) & $\begin{array}{c}\text { Harga Total } \\
\text { (Rp) }\end{array}$ \\
\hline 1 & Pisau & 3 & Buah & 30.000 & 90.000 \\
2 & Talenan kayu besar & 3 & Buah & 42.000 & 126.000 \\
3 & Baskom besar & 3 & Buah & 35.000 & 105.000 \\
4 & Deep frayer & 1 & Unit & 900.000 & 900.000 \\
5 & Sealer press & 1 & Unit & 235.000 & 235.000 \\
6 & Spinner & 1 & Unit & 2.200 .000 & 2.200 .000 \\
7 & Alat pengiris kentang & 3 & unit & 65.000 & 195.000 \\
\hline \multicolumn{5}{c}{ Jumlah (Rp) } \\
\hline
\end{tabular}

Besarnya nilai investasi tersebut digunakan untuk menghitung besarnya biaya penyusutan peralatan dan bunga modal yang akan mempengaruhi biaya produksi. perhitungan biaya produksikeripik kentang dilakukan berdasarkan data dan beberapa asumsi yang dapat dilihat pada Tabel 2.

Tebel 2 Variabel data dan asumsi usaha produksi keripik kentang

\begin{tabular}{|c|c|c|c|c|}
\hline No & Uraian & Nilai & Satuan & Keterangan \\
\hline 1 & Umur Proyek & 5 & Tahun & $\begin{array}{l}\text { berdasarkan umur } \\
\text { ekonomis tenaga } \\
\text { penggerak }\end{array}$ \\
\hline 2 & Suku Bunga Bank & 9 & $\%$ efektif & kredit usaha rakyat (kur) \\
\hline 3 & Biaya sewa tempat usaha & 5.000 .000 & Rp/tahun & asumsi \\
\hline 4 & nilai rongsok peralatan & 10 & $\begin{array}{l}\% \text { dari harga } \\
\text { investasi }\end{array}$ & asumsi \\
\hline 5 & Biaya perawatan peralatan & 2 & $\begin{array}{l}\text { \% dari biaya } \\
\text { investasi }\end{array}$ & asumsi \\
\hline 6 & Manajemen & 1.500 .000 & Rp/bulan & asumsi \\
\hline 7 & Jam kerja (hari) & 8 & Jam/hari & kondisi real \\
\hline 8 & Jam kerja (bulan) & 10 & hari/bulan & kondisi real \\
\hline 9 & Kapasitas pengupasan manual & 7,512 & $\mathrm{~kg} / \mathrm{jam}$ & hasil pengukuran \\
\hline 10 & Bahan baku kentang industri & 601 & $\mathrm{Kg} / \mathrm{bulan}$ & $\begin{array}{l}\text { jam kerja } \mathrm{x} \text { kapasitas } \\
\text { pengupasan }\end{array}$ \\
\hline 11 & Harga bahan baku & 10.000 & & real \\
\hline 12 & $\begin{array}{l}\text { Rendemen kentang terkupas } \\
\text { terhadap umbi kentang }\end{array}$ & 88,71 & $\%$ & hasil pengukuran \\
\hline 13 & Rendemen keripik kentang & 26,451 & $\%$ & hasil perhitungan \\
\hline 14 & Keripik kentang yang dihasilkan & 159 & $\mathrm{Kg} / \mathrm{bulan}$ & bahan baku $x$ rendemen \\
\hline 15 & Harga kemasan (Kapasitas 1 kg) & 850 & Rp/kemasan & hasil survei \\
\hline
\end{tabular}




\begin{tabular}{clcll}
\hline No & \multicolumn{1}{c}{ Uraian } & Nilai & \multicolumn{1}{c}{ Satuan } & \multicolumn{1}{c}{ Keterangan } \\
\hline 16 & Daya motor listrik & 1,50 & $\mathrm{HP}$ & kondisi real \\
& & 1,12 & $\mathrm{~kW}$ & kondisi real \\
17 & Lama operasi & 1 & jam/hari & asumsi \\
& & 10 & jam/bulan & asumsi \\
18 & Harga listrik PLN 1300 VA & $1.467,28$ & $\mathrm{Rp} / \mathrm{kwh}$ & $\mathrm{pln}$ \\
19 & Biaya Energi listrik & $16.412,26$ & $\mathrm{Rp} / \mathrm{bulan}$ & perhitungan \\
20 & Konsumsi Bahan bakar gas & 0,30 & $\mathrm{~kg} / \mathrm{hari}$ & asumsi \\
21 & Harga gas & 12.083 & $\mathrm{Rp} / \mathrm{kg}$ & harga pasaran \\
22 & Upah kerja & 70.000 & $\mathrm{Rp} / \mathrm{hari}$ & kondisi real \\
23 & Jumlah tenaga kerja harian & 4 & orang & kondisi real \\
24 & Penggunaan minyak goreng & 20 & liter untuk 4 & kondisi real \\
& menggunaka deep fraying & & hari produksi & \\
25 & Kebutuhan minyak goreng & 50,00 & $\mathrm{~kg} / \mathrm{bulan}$ & pengukuran \\
26 & Harga minyak goreng nasional & 11.410 & $\mathrm{Rp} / \mathrm{liter}$ & http://www.kemendag.go. \\
& & & & id/id \\
27 & Biaya minyak goreng & 570.500 & $\mathrm{Rp} / \mathrm{bulan}$ & perhitungan \\
28 & Harga keripik kentang utuh & 100.000 & $\mathrm{Rp} / \mathrm{kg}$ & real \\
29 & Harga keripik kentang tidak utuh & 60.000 & $\mathrm{Rp} / \mathrm{kg}$ & real \\
& & & & \\
\hline
\end{tabular}

\section{b. Penentuan Biaya Produksi Keripik Kentang}

Biaya produksi keripik kentang dipengaruhi oleh biaya tetap dan biaya variabel. Bila usaha dikelola secara propesional maka dalam perhitungan biaya tetap diasumsikan mengeluarkan biaya sewa tempat dan biaya manajemen (karyawan tetap pengelola usaha). Sedangkan biaya bunga modal berasal dari asumsi bahwa seluruh biaya investasi peralatan adalah dana pinjaman dari lembaga keuangan. Biaya penyusutan diperhitungkan menggunakan persamaan (1), maka berdasarkan perhitungan dengan menggunakan data pada Tabel 2 , besarnya biaya tetap dapat dilihat pada Tabel 3 .

Berdasarkan Tabel 3 terlihat bahwa besarnya biaya tetap usaha produksi keripik kentang adalah Rp. 2.009.733/bulan atau Rp. 24.116.790/tahun. Selain biaya tetap, terdapat biaya variabel yang besarnya ditentukan oleh banyak sedikitnya keripik kentang yang diproduksi. Biaya variabel terdiri atas biaya bahan baku berupa ubi kentang, kemasan plastik, energi listrik, bahan bakar gas dan upah kerja. Rincian biaya variabel dapat dilihat pada Tabel 4.

Tabel 3. Biaya tetap usaha produksi keripik kentang

\begin{tabular}{|c|c|c|c|}
\hline No & $\begin{array}{c}\text { Komponen } \\
\text { Biaya }\end{array}$ & $\begin{array}{l}\text { Biaya Tetap } \\
\text { (Rp/Tahun) }\end{array}$ & $\begin{array}{l}\text { Biaya Tetap } \\
\text { (Rp/Bulan) }\end{array}$ \\
\hline 1 & $\begin{array}{l}\text { Biaya } \\
\text { penyusutan } \\
\text { peralatan }\end{array}$ & 693.180 & 57.765 \\
\hline 2 & $\begin{array}{l}\text { Biaya sewa } \\
\text { tempat usaha }\end{array}$ & 5.000 .000 & 416.667 \\
\hline 3 & $\begin{array}{l}\text { Biaya } \\
\text { perawatan } \\
\text { peralatan }\end{array}$ & 77.020 & 6.418 \\
\hline 4 & Manajemen & 18.000 .000 & 1.500 .000 \\
\hline \multirow[t]{2}{*}{5} & Bunga modal & 346.590 & 28.883 \\
\hline & Total (Rp) & 24.116 .790 & 2.009 .733 \\
\hline
\end{tabular}


Tabel 4. Biaya variabel usaha produksi keripik kentang

\begin{tabular}{clc}
\hline No & Komponen Biaya & $\begin{array}{c}\text { Biaya Variabel } \\
\text { (Rp/Jam) }\end{array}$ \\
\hline 1 & Bahan baku & 75.120 \\
& kentang industri & \\
2 & Kemasan & 1.689 \\
3 & Energi listrik & 1.641 \\
4 & Bahan bakar gas & 453 \\
5 & Upah kerja & 8.750 \\
6 & Minyak goreng dan & 7.131 \\
& bumbu \\
\hline \multicolumn{2}{l}{ Total (Rp) } \\
\hline
\end{tabular}

Berdasarkan Tabel 4, terlihat bahwa besarnya biaya variabel usaha produksi keripik kentang adalah Rp. 121.035/jam. Besarnya biaya tetap dan biaya variabel selanjutnya digunakan untuk menghitung besarnya biaya produksi keripik kentang menggunakan persamaan (4), yaitu : $B P=B T$ $+B V^{*} X$

Berdasarkan perhitungan diketahui bahwa :

BT = Rp. 2.009.733/bulan

BV $=$ Rp. $121.035 / \mathrm{jam}$

$\mathrm{X}=8$ jam $/$ hari $\times 10$ hari $/$ bulan $=80$ jam/bulan

Sehingga besarnya biaya produksi (BP) adalah : Rp. 11.692.496/bulan

\section{c. Harga Pokok Produksi (HPP) Keripik Kentang}

Harga pokok produksi keripik kentang besarnya biaya produksi dan banyaknya kentang yang diproduksi. Besarnya harga pokok produksi (HPP) diperhitungkan menggunakan persamaan (5).

Berdasarkan perhitungan diketahui bahwa :

$\mathrm{BP}=$ Rp. 11.692.496/bulan

$\mathrm{PT}=159 \mathrm{~kg} / \mathrm{bulan}$
Sehingga besarnya harga pokok produksi (HPP) adalah : Rp. $73.556 / \mathrm{kg}$

\section{d. Analisis Titik Impas (BEP) Usaha Keripik Kentang}

Titik impas produksi merupakan titik dimana suatu usaha balik modal. Besar titik impas dipengaruhi oleh harga jual, biaya tetap total dan biaya variabel rata-rata. Berdasarkan hasil wawancara, keripik kentang yang diproduksi dijual dengan harga Rp. 100.000/kg maka besarnya titik impas produksi keripik kentang siap konsumsi yang dihitung menggunakan persamaan (6) adalah $612 \mathrm{~kg} /$ tahun atau 51 $\mathrm{kg} / \mathrm{bulan}$. Menurut Cafah (2009), suatu usaha dalam posisi yang menguntungkan apabila besarnya titik impas produksi lebih kecil dari rencana produksi.

\section{e. Perkiraan Pendapatan dan Keuntungan Usaha}

Pendapatan usaha keripik kentang didapat dari hasil penjualan keripik kentang yang diasumsikan pada bulan ke-1 sampai bulan ke-3 hanya $60 \%$ keripik kentang yang terjual, bulan ke-4 sampai bulan ke- 6 sebanyak $80 \%$ keripik kentang terjual dan pada bulan ke-7 sampai bulan ke-60 sebanyak $100 \%$ keripik kentang hasil produksi terjual.

Berdasarkan hasil pengukuran keripik kentang hasil irisan menggunakan alat pengiris dalam bentuk utuh sebanyak 87,92 $\%$ sedangkan yang tidak utuh sebanyak $12,08 \%$. Berdasarkan hasil wawancara harga keripik kentang yang tidak utuh adalah $60 \%$ dari harga keripik kentang utuh, dimana harga keripik kentang utuh adalah Rp. $100.000 / \mathrm{kg}$. Berdasarkan perhitungan kapasitas produksi keripik kentang adalah $159 \mathrm{~kg} /$ bulan maka besarnya pendapatan 
dari keripik kentang utuh dan keripik kentang tidak utuh pada tahun pertama adalah Rp. 154.303.917/tahun pada tahun kedua sampai tahun kelima adalah Rp.181.580.544 /tahun. Rincian pemasukan dan pengeluaran keuangan selama umur proyek dapat dilihat pada Tabel 5 .

Tabel 5. Keuntungan usaha produksi keripik kentang

\begin{tabular}{cccc}
\hline Tahun & $\begin{array}{c}\text { Pemasukan } \\
\text { (Rp/tahun) }\end{array}$ & $\begin{array}{c}\text { Pengeluaran } \\
((\text { Rp/tahun) })\end{array}$ & $\begin{array}{c}\text { Keuntungan } \\
\text { (Rp/tahun) }\end{array}$ \\
\hline 0 & 0 & 3.851 .000 & $(3.851 .000)$ \\
1 & 154.303 .917 & 140.309 .946 & 13.993 .971 \\
2 & 181.534 .020 & 140.309 .946 & 41.224 .074 \\
3 & 181.534 .020 & 140.309 .946 & 41.224 .074 \\
4 & 181.534 .020 & 140.309 .946 & 41.224 .074 \\
5 & 181.534 .020 & 140.309 .946 & 41.224 .074 \\
\hline
\end{tabular}

Berdasarkan Tabel 5 terlihat bahwa pada tahun ke-0 belum didapatkan keuntungan bahkan harus melakukan investasi peralatan sebesar Rp. 3.851 .000 sedangkan pada tahun pertama didapatkan keuntungan usaha sebesar Rp.13.993.971/tahun hal ini dipengaruhi oleh penjualan keripik kentang yang diasumsikan belum stabil sedangkan pada tahun kedua dan seterusnya didapatkan pendapatan keripik kentang sebesar Rp. 41.224.074/tahun.

\section{f. Analisis Kelayakan Investasi}

Analisis kelayakan investasi sangat diperlukan sebelum kita merencanakan suatu kegiatan usaha dengan tujuan untuk memperoleh kepastian pendapatan dari usaha yang menginvestasikan alat dan mesin (Iqbal dkk, 2012). Analisis kelayakan investasi disajikan dalam empat bentuk yaitu : Net Present Value (NPV), Internal Rate of Return (IRR), Net Benefit Cost Ratio (Net B/C) dan Payback Period (PBP). Suatu usaha dinyatakan layak apabila NPV $>0$, Net $B / C>$ 1, IRR > Suku bunga MARR dan PBP semakin cepat semakin baik (Kastaman, 2004). Analisis ini dilakukan dengan mengetahui komponen biaya pengeluaran dan pendapatan selama satu waktu periode produksi.

\section{1) Net Present Value (NPV)}

Selama periode analisis besarnya pengeluaran berupa investasi peralatan diawal proyek yaitu Rp. 3.851.000 dan biaya produksi yang berasal dari penjumlahan biaya tetap dan biaya variabel keripik kentang siap konsumsi yaitu Rp. 140.309.946/tahun, dan pendapatan berasal dari hasil penjualan keripik kentang siap konsumsi pada tahun pertama sebesar Rp. 154.303.917/tahun pada tahun kedua sampai tahun kelima adalah Rp.181.534.020/tahun dan nilai akhir peralatan yang diasumsikan $10 \%$ dari harga awal yaitu Rp. 385.100. Cash flow diagram dapat dilihat pada Gambar 2, dimana besarnya pemasukan ditunjukkan dengan anak panah ke atas sedangkan besarnya pengeluaran ditunjukkan dengan anak panah ke bawah. 
181.534 .020

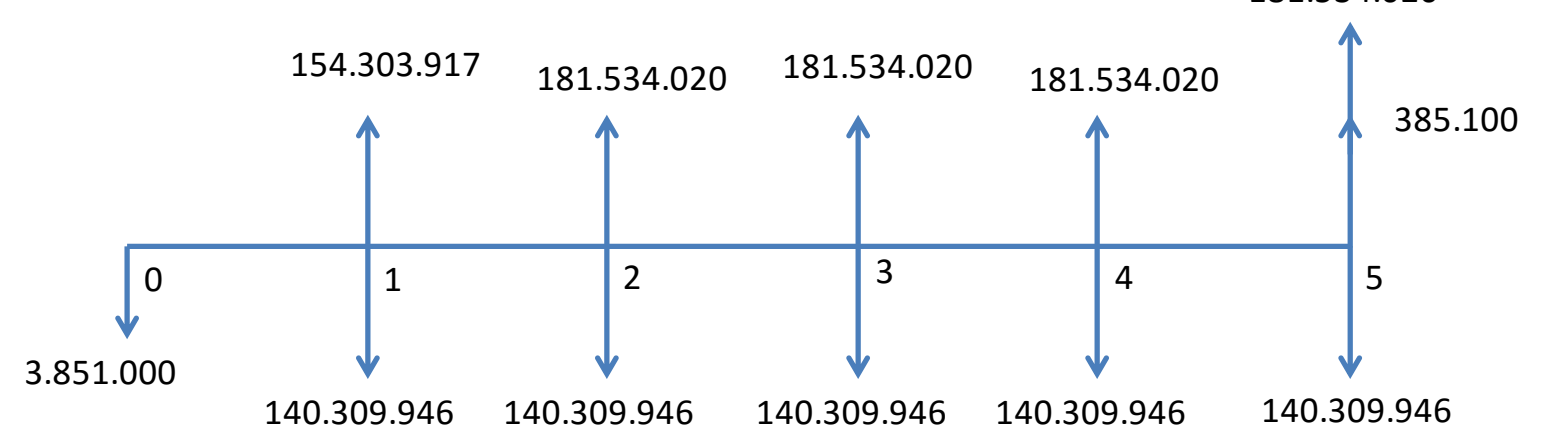

Gambar 2. Cash flow diagram pengolahan keripik kentang siap konsumsi

Berdasarkan Gambar 2 maka besarnya nilai sekarang pemasukan bersih dan pengeluaran bersih untuk usaha keripik kentang siap konsumsi dihitung pada bunga yang berlaku untuk kredit usaha rakyat (KUR) yaitu sebesar 9 $\%$ sehingga didapat nilai sekarang pemasukan bersih sebesar Rp. 681.372.573/tahun nilai sekarang pengeluaran bersih Rp.549.607.760 /tahun sehingga besarnya nilai NPV yang dihitung mengunakan persamaan (6) adalah sebesar Rp. 131.764.813/tahun, karena NPV > 0 maka usaha dinyatakan layak.

\section{2) Net Benefit Cost Ratio (Net B/C)}

Net $\mathrm{B} / \mathrm{C}$ merupakan perbandingan antara nilai sekarang dari penerimaan atau pendapatan yang diperoleh dari kegiatan investasi dengan nilai sekarang dari pengeluaran (biaya) selama investasi tersebut berlangsung dalam kurun waktu 5 tahun. Besarnya Net B/C yang dihitung menggunakan persamaan (7) adalah 1,24 dimana nilai tersebut dapat dikatakan layak karena Net $B / C>1$.

\section{3) Internal Rate of Return (IRR).}

IRR adalah suatu nilai penunjuk yang identik dengan seberapa besar suku bunga yang dapat diberikan oleh investasi tersebut dibandingkan dengan suku bunga bank yang berlaku umum (suku bunga pasar atau Minimum Attractive Rate of Return /MARR). Suku bunga MARR yang diacu pada penelitian ini adalah suku bunga kredit usaha rakyar mikro PT. Bank Republik Indonesia, Tbk yaitu sebesar $9 \%$ efektif pertahun. Pada suku bunga IRR akan diperoleh NPV $=0$, dengan perkataan lain bahwa IRR tersebut memberikan NPV=0. Perhitungan IRR dilakukan menggunakan persamaan (8). Berdasarkan hasil perhitungan besarnya IRR usaha keripik kentang siap konsumsi adalah 15,63\% dimana nilai tersebut $>$ bunga MARR.

\section{4) Payback Period (PBP)}

PBP mengindikasikan seberapa cepat modal atau investasi yang telah dikeluarkan dapat segera kembali berdasarkan pemasukan dan pengeluaran dari usaha yang dilakukan. Pendapatan usaha keripik kentang didapat dari hasil penjualan keripik kentang yang diasumsikan pada bulan ke-1 sampai bulan ke-3 hanya $60 \%$ keripik kentang yang terjual dan pada bulan ke-4 sampai bulan ke- 6 sebanyak $80 \%$ keripik kentang terjual serta pada 
bulan ke-7 sampai bulan ke-60 sebanyak $100 \%$ keripik kentang hasil produksi terjual semua. Rincian pemasukan dan pengeluaran keuangan dapat dilihat pada Tabel 6.

Tabel 6. Pemasukan dan pengeluaran keuangan produksi keripik kentang

\begin{tabular}{crrr}
\hline Bln & $\begin{array}{c}\text { Pemasukan } \\
\text { (Rp/bulan) }\end{array}$ & $\begin{array}{c}\text { Pengeluaran } \\
\text { (Rp/bulan) }\end{array}$ & \multicolumn{1}{c}{$\begin{array}{c}\text { Saldo } \\
\text { (Rp/bulan) }\end{array}$} \\
\hline 0 & 0 & 3.851 .000 & $(3.851 .000)$ \\
1 & 9.076 .701 & 11.692 .496 & $(6.466 .795)$ \\
2 & 9.076 .701 & 11.692 .496 & $(9.082 .589)$ \\
3 & 9.076 .701 & 11.692 .496 & $(11.698 .384)$ \\
4 & 12.102 .268 & 11.692 .496 & $(11.288 .611)$ \\
5 & 12.102 .268 & 11.692 .496 & $(10.878 .839)$ \\
6 & 12.102 .268 & 11.692 .496 & $(10.469 .066)$ \\
7 & 15.127 .835 & 11.692 .496 & $(7.033 .727)$ \\
8 & 15.127 .835 & 11.692 .496 & $(3.598 .387)$ \\
9 & 15.127 .835 & 11.692 .496 & $(163.048)$ \\
10 & 15.127 .835 & 11.692 .496 & 3.272 .292 \\
11 & 15.127 .835 & 11.692 .496 & 6.707 .631 \\
12 & 15.127 .835 & 11.692 .496 & 10.142 .971 \\
\hline
\end{tabular}

Berdasarkan Tabel 6 terlihat bahwa saldo bernilai positif pada bulan ke-10. Hal ini menunjukkan pada bulan ke-10 usaha produksi mulai mendapatkan keuntungan atau modal investasi telah kembali.

\section{KESIMPULAN}

1) Besarnya biaya produksi keripik kentang adalah sebesar Rp. 11.692.496 perbulan dan harga pokok produksi sebesar Rp. 73.556 perkg.

2) Titik impas produksi keripik kentang adalah $612 \mathrm{~kg}$ pertahun atau $51 \mathrm{~kg}$ perbulan yang dipengaruhi oleh harga jual, biaya tetap total dan biaya variabel rata-rata

3) Berdasarkan analisis kelayakan investasi, didapatkan BC rasio sebesar 1,24, NPV sebesar Rp.131.764.813 pertahun, IRR sebesar 15,63\%, PBP selama 10 bulan investasi sudah kembali.

\section{UCAPAN TERIMA KASIH}

Ucapan terima kasih diberikan kepada Universitas Padjadjaran yang telah memberikan bantuan biaya penelitian melalui skema Riset Bidang Pemula Unpad (RDPU) dan Taman Teknologi Pertanian, Cikajang, Garut yang telah memberikan bantuan fasilitas penelitian

\section{DAFTAR PUSTAKA}

Asgar A., Budiman D.A., Taufik Y. 2012. Pengaruh tipe mesin pengiris dan varietas terhadap kualitas irisan Kentang (Solanum tuberosum L.). Jurnal Teknotan 6(3) : 822828

SNI 01-3175-1992 tentang Kentang Segar. Badan Standarisasi Nasional, Jakarta.

Bank Indonesia (BI). 2017. Pola Pembiayaan Usaha Kecil ; Budidaya Kentang Industri. Direktorat Kredit, BPR dan UMKM. Bank Indonesia, Jakarta.

Cafah G.F. 2009. Analisis biaya produksi pada usaha produksi tahu di pabrik tahu Bandung Raos Cap Jempol, Dramaga, Bogor [Skripsi]. Fakultas Teknologi Pertanian, Institut Pertanian Bogor.

Iqbal, Mandang T, Sembiring E.N, Chozin M.A. 2012. Aspek teknologi dan analisis kelayakan pengelolaan serasah tebu pada perkebunan tebu lahan kering. Jurnal Keteknikan Pertanian 26 (1) : 17 - 23

Kastaman R. 2004. Ekonomi Teknik Untuk Pengembangan Kewirausahaan. Bandung (ID) ; Pustaka Giratuna dan ELOC-UNPAD.

Kusandriani, Y. 2014. Uji daya hasil dan kualitas delapan genotip kentang untuk industri keripik kentang nasional. Jurnal Hortikultura 24(4) : 283-288

Nagara R.M.S. 2016. Validasi metode pendugaan umur simpan keripik kentang dengan metode kadar air kritis (Skripsi). Fakultas 
Teknologi Pertanian, Institut Pertanian Bogor, Bogor.

Pramudya, B. dan N. Dewi. 1992. Ekonomi Teknik. Institut Pertanian Bogor, Bogor.

Rahayu R.E. dan Kartika L. 2015. Analisis kelembagaan dan srategi peningkatan daya saing komoditas kentang di Kabupaten Banjarnegara, Jawa Tengah. Jurnal Ilmu Pertanian Indonesia 20 (2) : 150157

Sofiari E, Tri Handayani, Helmi Kurniawan, Kusmana, Laksminiwati Prabaningrum, dan Nikardi Gunadi. 2015. Komoditas kentang sumber karbohidart bergizi dan ramah lingkungan. Terdapat pada Buku Inovasi
Hortikultura Pengungkit Peningkatan Pendapatan Rakyat. Badan Penelitian dan Pengembangan Pertanian, Kementerian Pertanian. IAARD Press, Jakarta. Hal. 79- 90. Syakir M. 2016. Taman Teknologi Pertanian (TTP) Cikajang, dukung peningkatan daya saing komoditas hortikultura. Press Release Badan Penelitian dan Pengembangan Pertanian Kementerian Pertanian tersedia pada

http://www.litbang.pertanian.go.id/press/o ne/50/pdf/Taman\%20Teknologi\%20Pertan ian\%20(TTP)\%20Cikajang,\%20Dukung\%20 Peningkatan\%20Daya\%20Saing\%20Komo ditas\%20Hortikultura.pdf [4 Januari 2016]. 